\title{
NTS Gene
}

National Cancer Institute

\section{Source}

National Cancer Institute. NTS Gene. NCI Thesaurus. Code C126484.

This gene may play a role in both fat digestion and antimicrobial activity. 